\title{
WATER RESERVE FOR THE ALVARADO COASTAL LAGOON WETLAND AS A MEASURE TO INCREASE RESILIENCE TO CLIMATE CHANGE
}

\author{
HÉCTOR SANVICENTE-SÁNCHEZ, \\ CERVANDO CASTILLO-ROMANO \& YOLANDA SOLÍS-ALVARADO \\ Sub coordination of Water Planning, Mexican Institute of Water Technology, México
}

\begin{abstract}
In Mexico, coastal zones are of great importance. The Inter-Census Population Survey 2015 establishes that 55.3 million of people live on 17 coastal states whose economic activities are tourism, fishing, commercial transportation and hydrocarbon exploitation, principally. Mexican coastal areas host a great diversity of ecosystems including rainforests, deserts, mangroves, dunes, wetlands, coral reefs and sea grass. Climatic change is considered as the main threat for the sustainability development of the countries, and costal zones are especially vulnerabilities. The National Water Reserves Program for the environment seeks to guarantee the volume of water required for the conservation of ecosystems and the maintenance of their ecosystem services as an ecosystem-based adaptation (EbA) measure that increases resilience and reduces the vulnerability of communities as well as produces several social, economic and environmental co-benefits. The present work updates the potential water reserve (PWR) score for all water supply basins to the Alvarado coastal lagoon wetland, estimates $16,807.33 \mathrm{Hm}^{3} /$ year as the minimum environmental flow (EF) that would serve as a water reserve for the wetland. Projected natural average annual runoffs (NAAR) were estimated in the area for three climate change scenario (RCP 4.5, RCP 6.0 and RCP 8.5) and for two time periods (2015-2039 and 2075-2099). As result, the RCP 4.5 scenario would be the most critical in the period 2015-2039 with a $9.7 \%$ of reduction with respect the historical NAAR, and the scenario RCP 8.5 would be the most critical for the period 2075-2099 with a $22.29 \%$ of reduction. It was concluded that the water reserve for the "Llanuras del Papaloapan" basin (Papaloapan plains basin), where the wetland is located, is feasible for such climatic change scenarios and time periods and can be carried out as an EbA measure. Further work must be done to establish the inter-annual eco-hydrological regime for the EF.
\end{abstract}

Keywords: environmental flow, water reserves, water availability, climate change, Alvarado lagoon.

\section{INTRODUCTION}

Coastal zones are of great importance for Mexican socioeconomic development. They cover 265 municipalities from which 151 are on the shoreline while 114 have high and medium coastal influence. This territory represents $21 \%$ of national continental surface area. According to the Inter-Census Population Survey 2015 [1], 55.3 million people live on 17 national coastal states equivalent to $44 \%$ of total population.

Mexican coastal zones also concentrate key economic activities [2], for example, tourism and fishing sectors represent $8.4 \%$ and $0.2 \%$ of Gross Domestic Product (GDP), respectively. While, commercial transportation and hydrocarbon exploitation equals $10 \%$ of GDP and has represented $37 \%$ of federal government income in the last 20 years.

From the environmental and ecologic perspective, Mexican coastal areas host a great diversity of ecosystems including rainforests, deserts, mangroves, dunes, wetlands, coral reefs and sea grass [3]. Mexico ranks among the top five countries in the world in terms of the extent of mangrove surface, for 2015 this surface extension was 775,555 ha. All these coastal ecosystems are the foundation of Mexican great coastal-marine biodiversity serving as nurseries areas and as a natural shield against extreme weather events. 


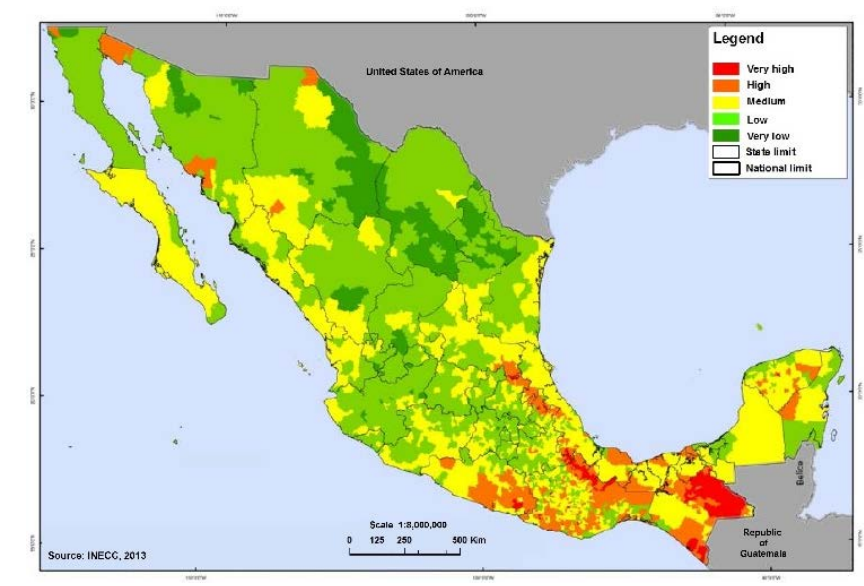

Figure 1: Climate change vulnerability at municipality level. (Source: INECC, 2013.)

In its Fifth Assessment Report (AR5) the Intergovernmental Panel on Climate Change (IPCC) [4], stablishes that "Warming of the climate system is unequivocal", "the atmosphere and ocean have warmed, the amounts of snow and ice have diminished, and sea level has risen" then the climatic system is changing and changes have caused and still causing impacts on natural and human systems. For example, in many regions climatic change is altering the hydrological cycle, affecting water resources in terms of quantity and quality.

Climatic change is considered as the main threat for the sustainability development of the countries, and costal zones are especially vulnerabilities. Reducing climate change risk would require implementation of mitigation and adaptation measures.

Regarding vulnerability to climate change, in Mexico, the National Institute of Ecology and Climate Change (INECC in Spanish) elaborated a qualitative analysis comparing different studies at national level [5]. The result was a map at municipality level which shows that, in general, coastal zones ranks vulnerability among medium and very high (see Fig. 1).

\section{OBJECTIVE}

Study objective is to calculate the water that must be reserved (water reserve), and let flow in the river network without assign to any socioeconomic use, required to maintain the health of the Alvarado Lagoon wetland and to evaluate the impact of this reserve on current and future water availability (for climate change sceneries) when considering conservation of the wetland as an ecosystem-based adaptation measure that increases resilience to climate change.

\section{NATIONAL WATER RESERVES PROGRAM}

The Mexican National Water Law (MNWL) [6], is based on Integrated Water Resources Management (IWRM) which is defined in the law as "the process that promotes the coordinated management and development of water, soil, resources related to these and the environment, with the aim of maximizing social and economic welfare without compromising the sustainability of vital ecosystems".

Despite IWRM, in Mexico, the water rights system, which is based on establishing water balances in each basin or administrative unit, has been being built postponing water to the environment allocation, on the grounds of lack of availability and information on 
environmental water needs, as well as, uncertainty about the application of scientifically appropriate and economically accessible methodologies to determine reliable environmental flow (EF). As a consequence, rights were granted in many watersheds in the country for one hundred percent or more of the average annual runoff and without regard to water intended for the environment.

To overcome the above, the Mexico water authority (National Water Commission, CONAGUA in Spanish) developed and published in 2012 the Mexican Standard NMX-AA159-SCFI-2012 [7], that establishes the procedure for environmental flow determination in hydrological basins. This Standard explicitly recognizes that a variable hydrological regime (beyond the minimum flows) with different components (low flows, avenues regime, etc). responsible for the ecosystem dynamics is necessary. In addition, it allows the establishment of environmental objectives from which to adjust EF's according to ecological importance and water use pressure in the watersheds. It integrates the social assessment of water in the environment and ensures its availability for the consumption and well-being of rural communities.

EF is defined as "the quantity, timing and quality of water flows required to sustain freshwater and estuarine ecosystems and the human livelihoods and well-being that depend on these ecosystems" [8]. It is recognized that EF is an indispensable condition for equitable and sustainable use of water resources and that EF allows to maintain a balance between the ecosystems water needs and their biota and the anthropogenic activities that depend on this flow.

Besides, Article 41 of MNWL [6], establishes that the Federal Executive (the President) may declare or suspend by means of a decree the reservation of national waters in total or partial way for: i) domestic and urban public use; ii) electric power generation for public service; (iii) ensure the minimum flows for ecological protection, including conservation or restoration of vital ecosystems.

Considering Article 41 of MNWL [6], as legal instrument and Mexican Standard NMXAA-159-SCFI-2012 [7], as technical and scientist tool, CONAGUA is implementing the National Water Reserves Program (NWRP) for the environment which consists in determine $\mathrm{EF}$ for the Mexican basins and reserve this volume through a decree.

The program was instituted based on a multicriteria analysis in which 189 watersheds were selected to have water reserves with a potential level [9], (see Fig. 2). This analysis established very strict criteria to identify low disturbed watersheds, with water availability and low water use pressure.

The NWRP for the environment seeks to guarantee the volume of water required for the conservation of ecosystems and the maintenance of their ecosystem services as an ecosystembased adaptation $(\mathrm{EbA})$ measure that increases resilience and reduces the vulnerability of communities as well as produces several social, economic and environmental co-benefits.

In coastal river basins such as those in the Hydrological Subregion Presidio-San Pedro river and in which the Alvarado Lagoon is located, water reserves are stablished to wetland conservation and preserve ecosystem services as water storage, aquifer recharge, storm protection, storm mitigation, coastal stabilization, erosion control, carbon sequestration, hydrologic cycle regulation, warehouse of energy, water cleaning, wood, support of a characteristic biodiversity, site of reproduction and feeding of numerous species of ecological and fishing interest and tourism possibilities. 


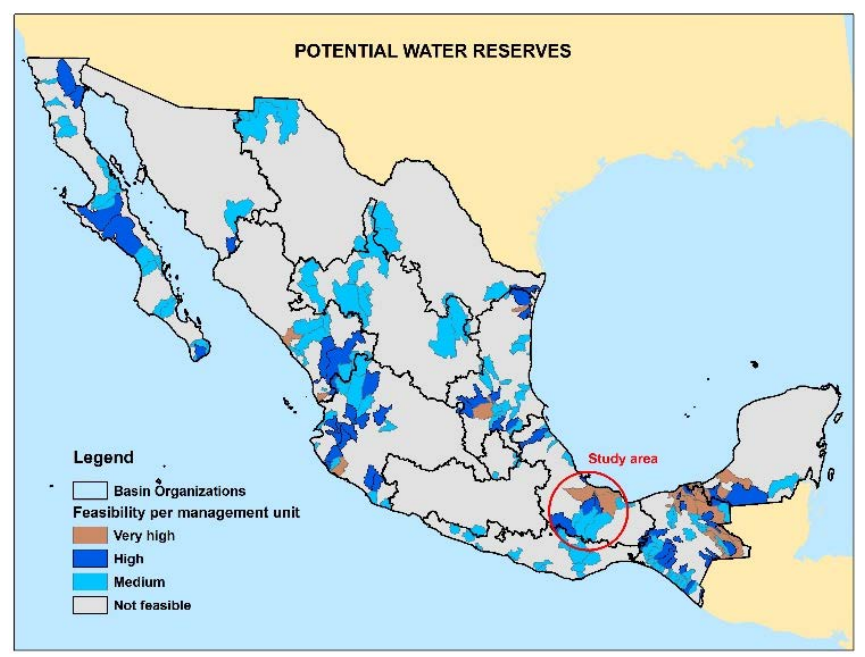

Figure 2: Watersheds into National Water Reserve Program. (Source: CONAGUA, 2011.)

\section{MEXICAN CLIMATIC CHANGE SCENARIOS}

For its Fifth National Communication to the United Nations Framework Convention on Climate Change (UNFCCC), Mexico carried out the updating of the climatic change scenarios for the country, through the generation of weighted assemblies, using the REA method, for the outputs of 14 general circulation models [10]. The database information of the Climatic Research Unit (CRU) from the University of East Anglia in England was used to the historical regional analysis of and the Representative Concentration Pathways (RCP) IPCC scenarios were used to climatic change future scenarios. The information generated establishes the absolute values of precipitation and temperature anomalies for the scenarios RCP 4.5, RCP 6.0 and RCP 8.5. Climate change scenarios were obtained for two periods of time called near future (2015-2039) and far future (2075-2099).

The Mexican climate change scenarios were processed to obtain relative anomalies (percentages of change in precipitation and temperature) that can be applied to different historical climate scenarios. Applying percentages of change to historical information generates total precipitation projections under the scenarios RCP 4.5, RCP 6.0 and RCP 8.5, for the periods 2015-2039 and 2075-2099.

\section{STUDY AREA}

The study area corresponds to the contribution area that hydrologically feeds the wetland of the Alvarado Lagoon, which is located towards the exit of the hydrological region 28 Papaloapan on the slope of the Gulf of Mexico and is distributed among the hydrological basins "Llanuras del Papaloapan" (Papaloapan plains) and "Blanco River". It is worth mentioning that the Blanco River basin drains into the "Llanuras del Papaloapan" basin, which is where most of the wetland extends. The hydrological region 28 is composed of 12 hydrological basins shown in Fig. 3.

"Llanuras del Papaloapan" basin was classified with a potential level "Very High" to content a water reserve, or with a very high Water Reserve Potential (WRP), in the CONAGUA's study of 2011 [9], (see Fig. 2). 


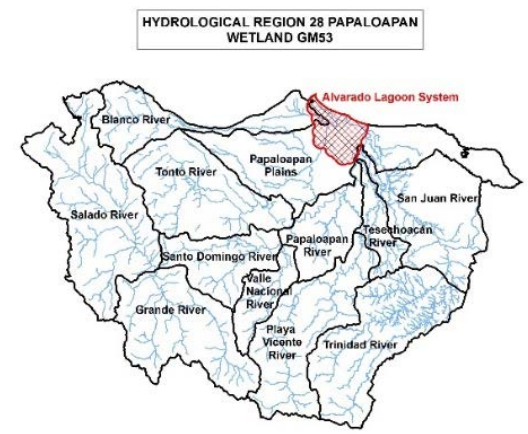

Figure 3: Contribution area that hydrologically feeds the wetland of the Alvarado lagoon.

The present work updates the WRP value for all the 12 water supply basins to the Alvarado coastal lagoon wetland, calculates the EF that would serve as a water reserve for the wetland according to the tables of the availability variables published in July 2016 [11], estimates the average annual runoff (AAR) for the climatic scenarios RCP 4.5, RCP 6.0 and RCP 8.5 generated for the 5th National Communication on Climate Change [10], considering as a reference or historical NAAR the availability 2016 [11], and establishes the impact of such estimates on runoff by own basin and on the availability of watersheds, as well as the feasibility of preserving the water reserve for the Llanuras del Papaloapan basin for such scenarios of climate change.

\section{METHODOLOGY}

The applied methodology consists of five big steps: 1) Update the feasibility of being a potential water reserve (PWR); 2) Estimate the environmental flow (EF) for "Llanuras del Papaloapan" basin, where the wetland is located; 3) Establish the impact of climate change on natural runoff; 4) Transfer impacts on runoff to water availability; and 5) Analyse the sustainability of the water reserve for climate change scenarios.

\subsection{Feasibility of being a potential water reserve}

In order to update the feasibility of being a PWR for all basins in the Hydrological region 28, the multicriteria evaluation methodology published in the document "Identification of Potential Reserves of Water for the Environment in Mexico" [9], was used. It is supported in the processing of coverages in a geographic information system (GIS).

The PWR feasibility of a basin is established from nine empirical variables (Table 1), each one evaluates three conditions or states of the variable: interpretation, criterion and weighting. The interpretation condition is conditioned by what is established in the criterion, the first two variables of the table are those that define if a basin can be incorporated or cannot be incorporated to the methodological process to obtain its feasibility; The rest of the variables are qualified with the positive or negative condition. With respect to the criterion, in seven variables is qualified from a numerical data, in two the condition of the variable is evaluated as presence or absence; Finally, the weighting assigns a numerical value in seven variables that is a consequence of the obtained in the criterion, in two its allocation depends on the obtained in the interpretation. 
Table 1: Potential water reserve variables (SupIA: Surface area of irrigation areas on the river basin; SupB: River basin surface area; StC: Reservoir storage capacity; IB: Water inputs to the basin (runoff by own basin and upstream water runoff); SupAq: Overexploited aquifers surface area). (Source: CONAGUA, 2011.)

\begin{tabular}{|c|c|c|c|}
\hline \multirow[t]{2}{*}{ Variable } & \multicolumn{3}{|c|}{ States } \\
\hline & Interpretation & Criterion & Weight \\
\hline Water availability (I) & Excluding & Availability $\leq \mathbf{0 ~ \mathrm { Hm } ^ { 3 }}$ & \\
\hline Use pressure & Excluding & Exploitation $\geq 10 \%$ & \\
\hline Water availability (II) & Positive & $\mathrm{Vol}>0 \mathrm{Hm}^{3}$ & 1 \\
\hline \multirow[t]{3}{*}{ Conservation importance } & Positive & Ramsar sites (presence) & 1 \\
\hline & Positive & $\begin{array}{l}\text { Natural protected areas } \\
\text { (presence) }\end{array}$ & 1 \\
\hline & Positive & $\begin{array}{l}\text { Total priority gaps for } \\
\text { aquatic conservation }>33\end{array}$ & 1 \\
\hline Closures (prohibitions) & Positive & Presence & 1 \\
\hline \multirow[t]{3}{*}{ Irrigation areas presence } & \multirow[t]{3}{*}{ Negative } & Sup $_{\text {IA }} / \operatorname{Sup}_{\text {B }} \leq 1 \%$ & 0 \\
\hline & & $1 \%<$ Sup $_{\text {IA }} / \operatorname{Sup}_{\text {B }} \leq 10 \%$ & -0.25 \\
\hline & & $\operatorname{Sup}_{\mathrm{IA}} / \operatorname{Sup}_{\mathrm{B}}>10 \%$ & -0.5 \\
\hline \multirow[t]{3}{*}{ Reservoir-Dams } & \multirow[t]{3}{*}{ Negative } & $\mathrm{StC} / \mathrm{I}_{\mathrm{B}} \leq 1 \%$ & 0 \\
\hline & & $1 \%<\mathrm{StC} / \mathrm{I}_{\mathrm{B}} \leq 10 \%$ & -0.25 \\
\hline & & $\mathrm{StC} / \mathrm{I}_{\mathrm{B}}>10 \%$ & -0.5 \\
\hline \multirow{3}{*}{$\begin{array}{l}\text { Overexploited } \\
\text { presence }\end{array}$} & \multirow[t]{3}{*}{ Negative } & $\operatorname{Sup}_{\mathrm{Aq}} / \mathrm{Sup}_{\mathrm{B}} \leq 1 \%$ & 0 \\
\hline & & $1 \%<\operatorname{Sup}_{\mathrm{Aq}} / \mathrm{Sup}_{\mathrm{B}} \leq 10 \%$ & -0.25 \\
\hline & & $\operatorname{Sup}_{\mathrm{Aq}} / \operatorname{Sup}_{\mathrm{B}}>10 \%$ & -0.5 \\
\hline \multirow{3}{*}{$\begin{array}{l}\text { Population } \\
(\text { Inhab/Km²) }\end{array}$} & \multirow[t]{3}{*}{ Negative } & Density $\leq 25$ & 0 \\
\hline & & $25<$ Density $\leq 50$ & -0.25 \\
\hline & & Density $>50$ & -0.5 \\
\hline
\end{tabular}

In order to carry out this updating, we considered the most current information such as surface water availability variables published in 2016 [11], Ramsar sites, protected natural areas (ANP), aquifers, existence of closures, etc.

The pressure on the unit of management, exploitation or use pressure is calculated as:

$$
U s e P r=\frac{U+E x+E v+A V}{N R+U S} .
$$

Where $U s e P r$ is the use pressure, $U$ is the annual volume of surface water extraction, $E X$ is the annual volume of exports, $E V$ the average annual volume of evaporation in reservoirs, $A V$ the average annual volume of storage variation in reservoirs, $N R$ is the mean annual volume of natural runoff and US is the mean annual volume of runoff from the upstream basin.

Adding the weights getting for each variable, result is a numerical value between -1 to 5 , this value represents the score obtained by the evaluated management unit; Finally, according to the score value obtained, it is assigned to a level of feasibility, which is the final result of the methodological process (Table 2). 
Table 2: PWR feasibility level according to score achieved. (Source: CONAGUA, 2011.)

\begin{tabular}{|l|c|}
\hline Feasibility Level & Score \\
\hline Very high & $4.25-5$ \\
\hline High & $3.25-4$ \\
\hline Medium & $2.25-3$ \\
\hline Not feasible & $\leq 2$ \\
\hline
\end{tabular}

Table 3: Reference Values to assign an environmental flow. (Source: CONAGUA, 2012.)

\begin{tabular}{|c|l|c|c|}
\hline \multirow{2}{*}{$\begin{array}{c}\text { Environmental } \\
\text { objective }\end{array}$} & \multirow{2}{*}{$\begin{array}{c}\text { Conservation } \\
\text { state }\end{array}$} & \multicolumn{2}{|c|}{ Environmental Flow (\% NAAR) } \\
\cline { 3 - 4 } & Perennial streams & Temporal streams \\
\hline A & Very good & $\geq 40$ & $\geq 20$ \\
\hline B & Good & $25-39$ & $15-19$ \\
\hline C & Moderate & $15-24$ & $10-14$ \\
\hline D & Deficit & $5-14$ & $5-9$ \\
\hline
\end{tabular}

\subsection{Environmental flow according to environmental objectives}

The environmental flow estimation was carried out using the hydrological methodology of the "Normative Appendix D" of the Mexican Standard NMX-AA-159-SCFI-2012 [7], for the "Llanuras del Papaloapan" basin, where most of the wetland is located. The hydrological methodology is to allocate a percentage of the natural average annual runoff volume (NAAR) flowing on the river, depending on the environmental objective of the river basin. The Mexican Standard NMX-AA-159-SCFI-2012 [7], defines four environmental objectives, named by letters A, B, C, D and that define a conservation state for a river basin. The environmental objectives for each of the country's hydrological basins are set out in the "Normative Appendix A" of NMX-AA-159-SCFI-2012 [7] and for the "Llanuras del Papaloapan" basin the environmental objective is "A". The NAAR percentage ranges for assigning an environmental flow volume according to "Normative Appendix D" are presented in Table 3.

\subsection{Average annual runoff calculation}

The natural average annual runoff in a watershed was estimated using the indirect method called precipitation-runoff, mentioned in the Official Mexican Standard NOM-011CONAGUA-2015 [12], by means of the following equation:

$$
N R=P * A * C r,
$$

where $N R$ is the mean annual volume of natural runoff that is produced by the river basin itself, $P$ is the annual mean precipitation over the river basin, $A$ is the river basin area and $\mathrm{Cr}$ is the runoff coefficient in the river basin.

The runoff coefficient $(\mathrm{Cr})$ for a year $\mathrm{j}$ is calculated as:

$$
C r_{j}=\frac{K\left(P_{j}-250\right)}{2000}, \text { Si } K \leq 0.15 ;
$$




$$
C r_{j}=\frac{K\left(P_{j}-250\right)}{2000}+\frac{K-0.15}{1.5}, \quad \text { Si } K \leq 0.15
$$

where $K$ is the infiltration parameter, $P_{j}$ is the annual mean precipitation for year $j$ and $C r_{j}$ is the runoff coefficient for year $j$.

\subsection{Annual average surface water availability}

The annual average surface water availability in a hydrological basin is determined in the main channel at the outlet of the basin using the following equations established by the Official Mexican Standard NOM-011-CONAGUA-2015 [12]:

$$
\begin{gathered}
S W A=D S-R x y, \\
D S=N R+U S+R+I m-(U+E v+E x+A V),
\end{gathered}
$$

where SWA is the annual average surface water availability in the hydrological basin, DS is the mean annual volume of runoff from the river basin to downstream, $R x y$ is the current annual volume committed downstream, $N R$ is the mean annual volume of natural runoff produced by the river basin itself, US is the mean annual volume of runoff from the upstream river basin, $R$ is the annual volume of returns, $I m$ is the annual volume of imports, $E v$ is the mean annual volume of evaporation in reservoirs, $E x$ is the annual volume of exports, $A V$ is the annual mean volume of storage variation in reservoirs and $U$ is the annual volume of surface water extraction which is integrated by the annual volume of surface water extraction by means of titles currently registered in the public register of water rights $(U a)$, annual volume of surface water extraction of titles in process of registration in the register of water rights $(U b)$ and the annual volume corresponding to the reserves, the environmental flow and the regulated areas $\left(U_{c}\right)$.

\section{RESULTS AND ANALYSIS}

The use pressure for the surface water for each river basin into the hydrological region 28 is obtained using the information published in the surface water availability 2016 [11], into eqn (1). The use pressure together with the superficial water availability determine if a river basin must be included or excluded for the potential water reserve analysis.

If one river basin is not excluded, the second step is overlapping and processing in a GIS the watershed layer with the Ramsar sites, ANPs, prohibited areas, reservoir-dams, aquifers, irrigation areas and population density in order to get information that can be used into Table 1. Weighting values for each variable were determined for each river basin of the study area to proceed to the sum of the same and with the information in Table 2 to get, the level of feasibility of be a potential water reserve that corresponds to them. Table 4 shows results obtained for the twelve river basins.

Table 4 shows that only five river basins have PWR feasibility, "Llanuras del Papaloapan" (Papaloapan Plains) and San Juan River have a high feasibility. As mentioned, the largest surface area of the Alvarado Lagoon is located in the Plains of Papaloapan basin and only a small part in the Blanco River basin, the last has a feasibility of exclusion because there is a very strong pressure on the water resource.

Table 3 was used to estimate the environmental flow (EF) in the "Llanuras del Papaloapan" river basin. Inputs to Table 3 were the environmental objective A and perennial stream. The "Normative Appendix A" of NMX-AA-159-SCFI-2012 [7], associates the 
Table 4: Updated PWR feasibility level of watersheds that feed Alvarado lagoon.

\begin{tabular}{|l|c|c|c|}
\hline \multicolumn{1}{|c|}{ Watershed } & PWR Feasibility & NR (Hm3/yr) & SWA (Hm3/yr) \\
\hline Salado River & Excluded & 377.382 & 157.10 \\
\hline Grande River & Medium & 854.593 & 301.65 \\
\hline Trinidad River & Not feasible & $6,332.03$ & $5,765.70$ \\
\hline Valle Nacional River & Not feasible & $3,806.66$ & $3,728.20$ \\
\hline Playa Vicente River & Not feasible & $6,121.80$ & $6,036.98$ \\
\hline Santo Domingo River & Excluded & $4,725.79$ & $2,576.36$ \\
\hline Tonto River & Excluded & $9,110.51$ & $11,739.98$ \\
\hline Blanco River & Excluded & $2,651.99$ & $2,055.05$ \\
\hline San Juan River & High & $2,284.11$ & $8,403.32$ \\
\hline Tesechoacán River & Medium & 494.359 & $6,531.03$ \\
\hline Papaloapan River & Medium & $1,309.06$ & $19,351.11$ \\
\hline Llanuras del Papaloapan & High & $3,950.03$ & $40,518.10$ \\
\hline \multicolumn{2}{|c|}{ Total } & $42,018.319$ & $40,518.10$ \\
\cline { 2 - 4 } & \multicolumn{2}{|c}{}
\end{tabular}

"Llanuras del Papaloapan" river basin with an environmental objective A. In this way, EF must be greater than or equal to $40 \%$ of NAAR.

It must be noted, that the NAAR in a river basin is equal to the NR plus NAAR that come upstream, then the NAAR is gotten adding the NR's of all the connected river basins upstream plus its own NR, in this case, the 12 watersheds that integrate the hydrological region 28 . The "Llanuras del Papaloapan" NAAR is $42,018.32 \mathrm{Hm}^{3}$; therefore, the EF or minimum water volume to be reserved is $16,807.33 \mathrm{Hm}^{3}(40 \%)$.

Table 4 shows that current availability of surface water in the "Llanuras del Papaloapan" river basin is $40,518.10 \mathrm{Hm}^{3}$, so that, the volume of $16,807.3 \mathrm{Hm}^{3}$ can be reserved without any problem. There would still be an availability of $23,710.77 \mathrm{Hm}^{3}$ that could be used in the "Llanuras del Papaloapan" basin itself or in watersheds connected upstream, since the idea would be to maintain the "Llanuras del Papaloapan" basin to function as an ecosystem-based adaptation (EbA) measure that increases resilience to climate change.

The third part of the methodology is to evaluate the impact of the climate change scenarios generated by Mexico for the 5th National Communication on Climate Change [10]. The geodatabase of climatic scenarios used has historical precipitation information for the 19712000 period, for the Climate Research Unit (CRU) of the University of East Anglia in England. In addition, it has the percentages of change in precipitation and the total precipitation projections for the climatic scenarios RCP 4.5, RCP 6.0 and RCP 8.5 for two periods called near future (2015-2039) and far future (2075-2099).

The mean annual precipitation for each river basin was gotten overlapping in a GIS the historical CRU precipitation information with the river basin cover and using a weighted average. The historical runoff coefficient $(\mathrm{Cr})$ was obtained using eqn (2) with the historical mean annual precipitation, $N R$ published in the surface water availability 2016 [11], (Table 4 ) and watershed areas. The basin infiltration parameter $(K)$ was estimated using eqn (4) with the historical $\mathrm{Cr}$ estimated and the historical mean annual precipitation. Table 5 shows the mean annual precipitation, the $\mathrm{Cr}$ and the $K$ for each river basin. Runoff coefficient, infiltration parameter and historical mean annual precipitation. 
Table 5: The mean annual precipitation, the $C r$ and the $K$ for each river basin.

\begin{tabular}{|l|r|r|r|r|r|}
\hline \multicolumn{1}{|c|}{ Watershed } & \multicolumn{1}{|c|}{$K$} & $\begin{array}{c}\text { Area } \\
\left(\mathrm{Km}^{2}\right)\end{array}$ & \multicolumn{1}{c|}{$\mathrm{Cr}$} & $\begin{array}{c}\text { Precip } \\
(\mathrm{mm} / \mathrm{yr})\end{array}$ & \multicolumn{1}{c|}{$\begin{array}{c}\mathrm{NR} \\
\left(\mathrm{Hm}^{3} / \mathrm{yr}\right)\end{array}$} \\
\hline Salado River & 0.21 & $6,598.24$ & 0.08 & 691.88 & 377.382 \\
\hline Grande River & 0.31 & $4,918.53$ & 0.20 & 870.81 & 854.593 \\
\hline Trinidad River & 0.46 & $5,344.86$ & 0.60 & $1,969.36$ & $6,332.03$ \\
\hline Valle Nacional River & 0.51 & $1,414.86$ & 0.92 & $2,924.51$ & $3,806.66$ \\
\hline Playa Vicente River & 0.56 & $4,673.60$ & 0.71 & $1,837.99$ & $6,121.80$ \\
\hline Santo Domingo River & 0.59 & $2,531.41$ & 0.86 & $2,170.93$ & $4,725.79$ \\
\hline Tonto River & 0.45 & $4,813.46$ & 0.72 & $2,613.24$ & $9,110.51$ \\
\hline Blanco River & 0.65 & $2,922.48$ & 0.68 & $1,330.77$ & $2,651.99$ \\
\hline San Juan River & 0.29 & $4,542.41$ & 0.30 & $1,690.29$ & $2,284.11$ \\
\hline Tesechoacán River & 0.25 & $1,147.03$ & 0.25 & $1,715.08$ & 494.359 \\
\hline Papaloapan River & 0.26 & $2,261.37$ & 0.29 & $1,975.69$ & $1,309.06$ \\
\hline Llanuras del Papaloapan & 0.28 & $6,432.26$ & 0.32 & $1,934.14$ & $3,950.03$ \\
\hline
\end{tabular}

Infiltration parameter $\mathrm{K}$ depends on the type of soil and vegetation, which, in this work, are assumed constant over time so that the parameter $\mathrm{K}$ remains constant also. However, the runoff coefficient $(\mathrm{Cr})$ changes in climatic scenarios, since it is a function of the average annual precipitation obtained for each period (near future 2015-2039 and far future 20752099) and each scenario (RCP4 .5, RCP6.0 and RCP8.5).

Using the same procedure of overlapping precipitation cover and basin layer the annual mean rainfall for each of the periods (near and far future) and climatic scenarios were estimated. The mean annual rainfall, for the climatic scenarios and periods, and the infiltration parameter $\mathrm{K}$, calculated for the historical information, fed equation (4) to obtain the runoff coefficients $(C r)$ by scenario and period. Finally, we used equation (2) to calculate the mean annual runoff for each basin, scenario and period.

From the results obtained, it was found that the most critical scenario for the near future (2015-2039) would be the RCP4.5 with a reduction in the total annual average runoff (of the entire contribution zone) from the historical of $9.70 \%$ (Table 6). For the far future (1975-2099), the most critical scenario would be RCP8.5 with a reduction in average annual runoff of $21.49 \%$ with respect the historical one (Table 7).

Once obtained impacts by climate change in the NR of each basin, they were transferred to the availability of surface water using equations (5) and (6). The information of uses $(U)$, returns $(R)$, Imports $(I m)$, Exports $(E x)$ and reservoirs $(E v$ and $A V)$ were maintained fixed and the estimated $R N$ 's for each basin, period and climatic scenario were used as the average annual volume of natural runoff per basin. It is noteworthy that the volume downstream (DS) becomes the volume upstream (US) of the basin that is connected to the output.

From Table 6 that represents the climatic scenario with the greatest impact for the near future, we can see that surface water availability would be $36,441.52 \mathrm{Hm}^{3}$ which represents a reduction of $10.6 \%$ with respect to availability published in 2016 [11]. However, such availability is enough to maintain the water reserve of $16,807.33 \mathrm{Hm}^{3}$ in "Llanuras del Papaloapan" river basin for the wetland and leaving a volume for other uses of 19,634.19 $\mathrm{Hm}^{3}$. For the far future (2075-2099) the surface water availability of $31,486.87 \mathrm{Hm}^{3} /$ year (Table 7) would allow maintaining the water reserve of the wetland leaving a volume of $14,679.54 \mathrm{Hm}^{3}$ for other uses. 
Table 6: Impact on NR and availability for scenario RCP4.5 in the period 2015-2039.

\begin{tabular}{|l|r|r|r|r|r|}
\hline \multicolumn{1}{|c|}{ Watershed } & Cr & $\begin{array}{c}\text { Precip } \\
(\mathrm{mm} / \mathrm{yr})\end{array}$ & $\begin{array}{c}\text { NR } \\
\left(\mathrm{Hm}^{3} / \mathrm{yr}\right)\end{array}$ & $\begin{array}{c}\text { NR } \\
\text { Anom } \\
(\%)\end{array}$ & \multicolumn{1}{c|}{$\begin{array}{c}\text { SWA } \\
\mathrm{Hm}^{3} / \mathrm{yr}\end{array}$} \\
\hline Salado River & 0.08 & 642.00 & 328.43 & -12.97 & 108.15 \\
\hline Grande River & 0.19 & 806.24 & 751.97 & -12.01 & 199.03 \\
\hline Trinidad River & 0.58 & $1,858.12$ & $5,720.48$ & -9.66 & $5,154.15$ \\
\hline Valle Nacional River & 0.89 & $2,791.32$ & $3,499.44$ & -8.07 & $3,420.98$ \\
\hline Playa Vicente River & 0.69 & $1,743.86$ & $5,594.84$ & -8.61 & $5,510.02$ \\
\hline Santo Domingo River & 0.82 & $2,048.67$ & $4,272.61$ & -9.59 & $1,971.60$ \\
\hline Tonto River & 0.69 & $2,470.25$ & $8,232.83$ & -9.63 & $10,862.30$ \\
\hline Blanco River & 0.65 & $1,241.63$ & $2,369.59$ & -10.65 & $1,772.65$ \\
\hline San Juan River & 0.28 & $1,590.18$ & $2,045.21$ & -10.46 & $7,552.86$ \\
\hline Tesechoacán River & 0.24 & $1,610.04$ & 439.73 & -11.05 & $5,949.45$ \\
\hline Papaloapan River & 0.28 & $1,863.45$ & $1,173.92$ & -10.32 & $17,426.31$ \\
\hline Llanuras del Papaloapan & 0.30 & $1,814.55$ & $3,512.70$ & -11.07 & $36,441.52$ \\
\hline & Total & & $37,941.74$ & -9.70 & $36,441.52$ \\
\cline { 2 - 6 }
\end{tabular}

Table 7: Impact on NR and availability for scenario RCP8.5 in the period 2075-2099.

\begin{tabular}{|l|r|r|r|r|r|}
\hline \multicolumn{1}{|c|}{ Watershed } & $\mathrm{Cr}$ & $\begin{array}{c}\text { Precip } \\
(\mathrm{mm} / \mathrm{yr})\end{array}$ & $\begin{array}{c}\mathrm{NR} \\
\left(\mathrm{Hm}^{3} / \mathrm{yr}\right)\end{array}$ & $\begin{array}{c}\mathrm{NR} \\
\text { Anom } \\
(\%)\end{array}$ & $\begin{array}{c}\text { SWA } \\
\mathrm{Hm} / \mathrm{yr}\end{array}$ \\
\hline Salado River & 0.07 & 569.82 & $\mathbf{2 6 3 . 5 8}$ & -30.16 & $\mathbf{4 3 . 2 9}$ \\
\hline Grande River & 0.17 & 709.98 & $\mathbf{6 1 0 . 6 7}$ & -28.54 & $\mathbf{5 7 . 7 3}$ \\
\hline Trinidad River & 0.55 & $1,724.07$ & $\mathbf{5 , 0 2 3 . 8 8}$ & -20.66 & $\mathbf{4 , 4 5 7 . 5 6}$ \\
\hline Valle Nacional River & 0.84 & $2,618.06$ & $\mathbf{3 , 1 1 8 . 8 9}$ & -18.07 & $\mathbf{3 , 0 4 0 . 4 2}$ \\
\hline Playa Vicente River & 0.65 & $1,617.24$ & $\mathbf{4 , 9 2 2 . 4 0}$ & -19.59 & $\mathbf{4 , 8 3 7 . 5 8}$ \\
\hline Santo Domingo River & 0.78 & $1,894.49$ & $\mathbf{3 , 7 3 2 . 9 7}$ & -21.01 & $\mathbf{1 , 2 2 5 . 8 1}$ \\
\hline Tonto River & 0.65 & $2,302.09$ & $\mathbf{7 , 2 5 6 . 9 2}$ & -20.35 & $\mathbf{9 , 8 8 6 . 3 9}$ \\
\hline Blanco River & 0.61 & $1,123.33$ & $\mathbf{2 , 0 1 8 . 0 1}$ & -23.91 & $\mathbf{1 , 4 2 1 . 0 7}$ \\
\hline San Juan River & 0.26 & $1,435.85$ & $\mathbf{1 , 7 0 2 . 4 6}$ & -25.47 & $\mathbf{6 , 5 1 3 . 5 2}$ \\
\hline Tesechoacán River & 0.22 & $1,463.23$ & $\mathbf{3 6 8 . 7 0}$ & -25.42 & $\mathbf{5 , 2 0 5 . 9 8}$ \\
\hline Papaloapan River & 0.26 & $1,713.82$ & $\mathbf{1 , 0 0 5 . 1 6}$ & -23.21 & $\mathbf{1 5 , 1 5 5 . 2 9}$ \\
\hline Llanuras del Papaloapan & 0.28 & $1,653.36$ & $\mathbf{2 , 9 6 3 . 4 5}$ & -24.98 & $\mathbf{3 1 , 4 8 6 . 8 7}$ \\
\hline & Total & & $32,987.09$ & -21.49 & $31,486.87$ \\
\cline { 2 - 6 }
\end{tabular}

\section{CONCLUSIONS}

Of the twelve hydrological basins that establish the water supply area to the Alvarado Lagoon Wetland, only 5 have potential to be water reserves with values ranging from medium to high. The "Llanuras del Papaloapan" river basin, where most of the wetland is located, has a high potential value and a sufficient surface water availability to establish a water reserve of $16,807.33 \mathrm{Hm}^{3} /$ year as an environmental flow to maintain the wetland and the health of the ecosystems.

From the analysis of the impact that climate change could have on the study area from the climatic scenarios RCP4.5, RCP6.0 and RCP8.5 for Mexico was concluded. For the near future (2015-2039) the scenario RCP4 .5 is the most critical and would produce a reduction 
in runoff of $9.70 \%$ which would impact on surface water availability as a $10.6 \%$ with respect to the availability 2016 [11]. For the far future, the reduction in runoff is $21.49 \%$ and in the surface water availability of $22.29 \%$. However, even with these impacts, the estimated water reserve could be maintained and have high availability values for the Papaloapan plains basin (Llanuras del Papaloapan). Further work must be done to establish the inter-annual ecohydrological regime for the EF.

\section{REFERENCES}

[1] Encuesta Intercensal 2015; Instituto Nacional de Estadística y Geografía (INEGI). www.beta.inegi.org.mx/proyectos/enchogares/especiales/intercensal. Accessed on: Apr. 2017.

[2] Sistema de Cuentas Nacionales, Banco de Información Económica (BIE); INEGI. www.inegi.org.mx/sistemas/bie. Accessed on: Apr. 2017.

[3] CONABIO, Estrategia Nacional sobre Biodiversidad de México y Plan de Acción 2016-2030, CONABIO: México, p. 383, 2016.

[4] IPCC, Climate Change 2014: Synthesis Report. Contribution of Working Groups I, II and III to the Fifth Assessment Report of the Intergovernmental Panel on Climate Change, Core Writing Team, Pachauri R.K. and Meyer L.A., (eds) IPCC: Geneva, Switzerland, p. 151, 2014.

[5] Vulnerabilidad al Cambio Climático en los Municipios de México; INECC, www.gob.mx/inecc/acciones-y-programas/vulnerabilidad-al-cambio-climatico-enlos-municipios-de-mexico. Accessed on: Apr. 2017.

[6] Cámara de Diputados del H. Congreso de la Unión, Ley de Aguas Nacionales, Diario Oficial de la Federación. México. Last reform: 24 Mar. 2016.

[7] CONAGUA, Declaratoria de vigencia de la Norma Mexicana NMX-AA-159-SCFI2012, Que establece el procedimiento para la determinación del caudal ecológico en cuencas Hidrológicas, Diario Oficial de la Federación. México. 20 Sep. 2012.

[8] Matthews, J.H et al., More than the fish: Environmental flows for good policy and governance, poverty alleviation and climate adaptation. Aquatic Procedia, 2, pp. 1623, 2014.

[9] CONAGUA, Identificación de reservas potenciales de agua para el medio ambiente en México. SEMARNAT, México, pp. 85, 2011.

[10] Cavazos, T. et al., Actualización de Escenarios de Cambio Climático para México como Parte de los Productos de la Quinta Comunicación Nacional, Informe Final. INECC, México, 2013.

[11] CONAGUA, Acuerdo por el que se actualiza la disponibilidad media anual de las aguas nacionales superficiales de las 757 cuencas hidrológicas que comprenden las 37 regiones hidrológicas en que se encuentra dividido los Estados Unidos Mexicanos, Diario Oficial de la Federación. México. 7 Jul. 2016.

[12] CONAGUA, Norma Oficial Mexicana NOM-011-CONAGUA-2015, Que establece las especificaciones y el método para determinar la disponibilidad media anual de las aguas nacionales, Diario Oficial de la Federación. México. 27 Mar. 2015. 